\title{
Effect of Cations on Aluminum Speciation Under Alkaline Conditions
}

\author{
K. M. L. Taylor-Pashow \\ D. T. Hobbs
}

July 2012

Savannah River National Laboratory Savannah River Nuclear Solutions, LLC Aiken, SC 29808

Prepared for the U.S. Department of Energy under contract number DE-AC09-08SR22470. 
SRNL-STI-2012-00136

Revision 0

\section{DISCLAIMER}

This work was prepared under an agreement with and funded by the U.S. Government. Neither the U.S. Government or its employees, nor any of its contractors, subcontractors or their employees, makes any express or implied:

1. warranty or assumes any legal liability for the accuracy, completeness, or for the use or results of such use of any information, product, or process disclosed; or

2. representation that such use or results of such use would not infringe privately owned rights; or

3. endorsement or recommendation of any specifically identified commercial product, process, or service.

Any views and opinions of authors expressed in this work do not necessarily state or reflect those of the United States Government, or its contractors, or subcontractors.

\section{Printed in the United States of America}

Prepared for

U.S. Department of Energy 
Keywords: boehmite, gibbsite, bayerite, aluminum, cations, alkaline

Retention: Permanent

\title{
Effect of Cations on Aluminum Speciation Under Alkaline Conditions
}

\author{
K. M. L. Taylor-Pashow \\ D. T. Hobbs
}

July 2012

Savannah River National Laboratory Savannah River Nuclear Solutions, LLC Aiken, SC 29808

Prepared for the U.S. Department of Energy under contract number DE-AC09-08SR22470. 


\section{REVIEWS AND APPROVALS}

AUTHORS:

K. M. L. Taylor-Pashow, Separations and Actinide Science Programs

Date

D. T. Hobbs, Separations and Actinide Science Programs

Date

TECHNICAL REVIEW:

F. F. Fondeur, Separations and Actinide Science Programs

Date

APPROVAL:

S. D. Fink, Manager

Date

Separations and Actinide Science Programs

S. L. Marra, Manager

Date

Environmental \& Chemical Process Technology Research Programs 


\section{EXECUTIVE SUMMARY}

A series of experiments were performed to examine the effect of metal cations common to high level waste on the phase of aluminum formed. Experiments were performed at temperature of $150{ }^{\circ} \mathrm{C}, 75^{\circ} \mathrm{C}$, and room temperature, either without additional metal cation, or with $0.01-0.2$ molar equivalents of either $\mathrm{Ni}^{2+}, \mathrm{Fe}^{3+}, \mathrm{Mn}^{2+}$, or $\mathrm{Cr}^{3+}$. Results showed that temperature has the greatest effect on the phase obtained. At $150{ }^{\circ} \mathrm{C}$, boehmite is the only phase obtained, independent of the presence of other metal cations, with only one exception where a small amount of gibbsite was also detected in the product when 0.2 equivalents of $\mathrm{Ni}^{2+}$ was present. At $75^{\circ} \mathrm{C}$, a mixture of phases is obtained, most commonly including bayerite and gibbsite; however, boehmite is also formed under some conditions, including in the absence of additional metal ion. At room temperature, in the absence of additional metal ion, a mixture of bayerite and gibbsite is obtained. The addition of another metal cation suppresses the formation of gibbsite, with a couple of exceptions ( 0.2 equivalents of $\mathrm{Ni}^{2+}$ or 0.01 equivalents of $\mathrm{Cr}^{3+}$ ) where both phases are still obtained. 


\section{TABLE OF CONTENTS}

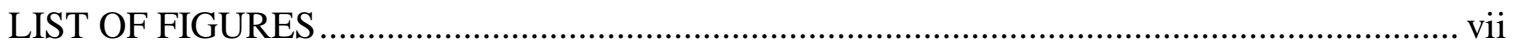

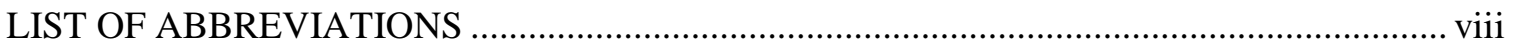

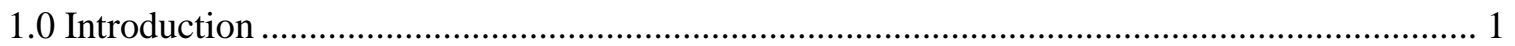

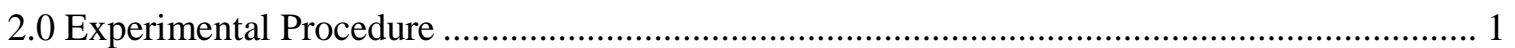

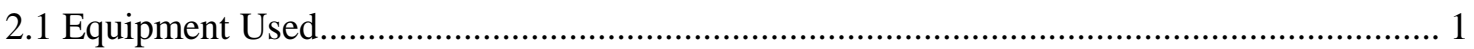

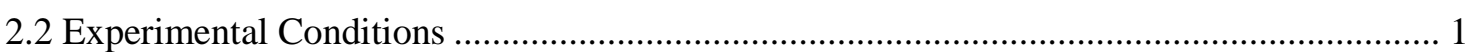

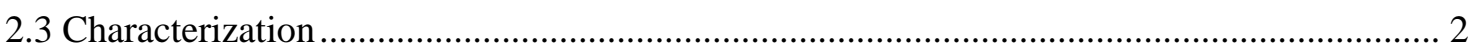

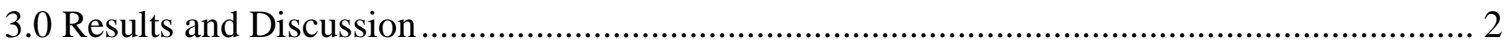

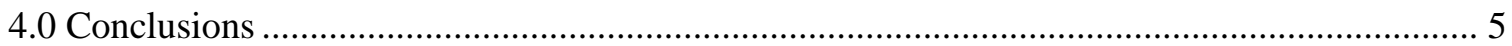

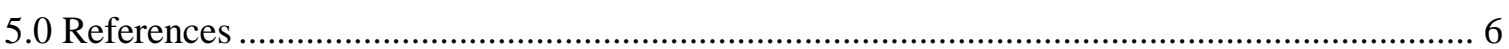




\section{LIST OF FIGURES}

Figure 3-1. PXRD of Test 30 showing the presence of both boehmite and gibbsite phases.......... 2

Figure 3-2. PXRD of Test 22 after variable times at $150{ }^{\circ} \mathrm{C}$. Results show the formation of only the boehmite phase for all time points. ..................................................................................... 3

Figure 3-3. PXRD of Test 71 compared to the PXRD of Tests $92-96$...................................... 4

Figure 3-4. PXRD of Test 71 and $92-96$ showing difference in peaks between $18-19^{\circ} 2$ theta. Test 71 shows a larger amount of bayerite as evidenced by the peak at $18.8^{\circ}$, whereas Tests 92-96 show larger amounts of gibbsite as evidenced by the peak at $18.3^{\circ}$. The peak at $\sim 18.5^{\circ}$ indicates the presence of nordstrandite, which appears to be absent in Test 71. 


\section{LIST OF ABBREVIATIONS}

$\begin{array}{ll}\text { HLW } & \text { High Level Waste } \\ \text { MARS } & \text { Microwave Accelerated Reactor System } \\ \text { PXRD } & \text { powder X-ray diffraction } \\ \text { SRNL } & \text { Savannah River National Laboratory }\end{array}$




\subsection{Introduction}

The high-level nuclear waste (HLW) stored at the Hanford and Savannah River sites consists of both solids and highly alkaline, high ionic strength salt solutions. ${ }^{1-3}$ The solids consist primarily of metal hydroxides and hydrated metal oxides, and are commonly referred to as sludge. The salt solutions typically feature hydroxide concentrations in excess of $1 \mathrm{M}$ free hydroxide, and sodium ion concentrations of several molar. Other major components of the salt solutions include nitrate, nitrite, carbonate, and aluminate.

Current plans for the permanent disposal of HLW include separation of the radioactive components from the bulk of the waste, and vitrification of this fraction in a glass waste form. ${ }^{3}$ The bulk of the sludge solids will be vitrified in the glass waste form. The amount of aluminum in the waste affects the total quantity of vitrified waste produced. To minimize the volume of vitrified waste produced, a caustic leaching step is planned to reduce the amount of aluminum in the sludge. The efficiency of the caustic leaching step is dependent upon the form of aluminum present in the sludge. The two most common phases of aluminum solids present in the sludge are gibbsite ( $\alpha$-aluminum trihydroxide, $\left.\alpha-\mathrm{Al}(\mathrm{OH})_{3}\right)$ and boehmite ( $\alpha$-aluminum oxyhydroxide, $\alpha$ $\mathrm{AlOOH})$. Gibbsite dissolves much more readily at moderate hydroxide concentrations and temperatures, in contrast to boehmite, which requires more aggressive conditions and dissolves slower.

The conditions under which the HLW has been stored include a wide range of ionic strength, temperature, and water content. Fresh HLW slurries can self-heat due to radioactive decay, frequently reaching temperature of $100-150{ }^{\circ} \mathrm{C} .{ }^{4}$ We performed a series of experiments designed to examine the effect of other common cations present in the HLW on the phase of aluminum formed.

\subsection{Experimental Procedure}

\subsection{Equipment Used}

For some of the experiments, a Microwave Accelerated Reactor System (MARS) was used to heat the reaction solutions to a constant temperature under pressure. The MARS system utilizes Teflon $^{\circledR}$ vessels which can be sealed and can withstand a pressure of up to 500 psi. The system then uses microwave energy to heat the solutions, as they are rotated in the oven. Temperature and pressure probes are used to constantly monitor the reaction conditions, and apply the appropriate power to maintain the temperature at the set point. The MARS was used for all experiments at $150{ }^{\circ} \mathrm{C}$, and some of the $75^{\circ} \mathrm{C}$ experiments. The remaining $75{ }^{\circ} \mathrm{C}$ experiments were performed in a shaker oven, using polyethylene bottles for the reactions. The room temperature experiments were performed by stirring the reaction mixtures in polyethylene bottles or glass vials.

\subsection{Experimental Conditions}

Appendix A provides a summary of all experiments performed. For each test, the appropriate amount of aluminum nitrate nonahydrate $\left[\mathrm{Al}\left(\mathrm{NO}_{3}\right)_{3} \cdot 9 \mathrm{H}_{2} \mathrm{O}\right]$ and metal nitrate salt (if used) was added to the reaction vessel. The appropriate amounts of distilled water and $50 \mathrm{wt} \%$ sodium hydroxide were then added. The amount of $\mathrm{NaOH}$ added was enough to provide 3 molar equivalents per $\mathrm{Al}$ and metal ion, plus a $20 \%$ excess. The contents of the vessels were then mixed gently before sealing the vessels and heating to the indicated temperature for the indicated time. After the reactions were complete, the solids were collected by filtration and washed with 
distilled water and ethanol. The solids were then dried in a vacuum oven at $50{ }^{\circ} \mathrm{C}$ for $6-24$ hours.

\subsection{Characterization}

Samples of the solids were analyzed using powder X-ray diffraction (PXRD) to determine the phase of material obtained.

\subsection{Results and Discussion}

PXRD was used to determine the phase of aluminum present in the product from each reaction. The results are summarized in Appendix A. The results indicate that under these conditions, boehmite was preferentially formed when the test mixtures were heated to $150{ }^{\circ} \mathrm{C}$, and that the presence of other cations did not affect the phase obtained, with one exception. In the presence of 0.2 molar equivalents of $\mathrm{Ni}^{2+}$, gibbsite was detected in addition to the boehmite; however, the amount was not significant (Test 30, Figure 3-1). A kinetic study in the absence of additional metal ion (Test 22) showed that boehmite is formed quickly (Figure 3-2). In this test boehmite was the only phase identified after only 5 minutes at temperature as well as the other heating times of 15, 45 and 60 minutes.

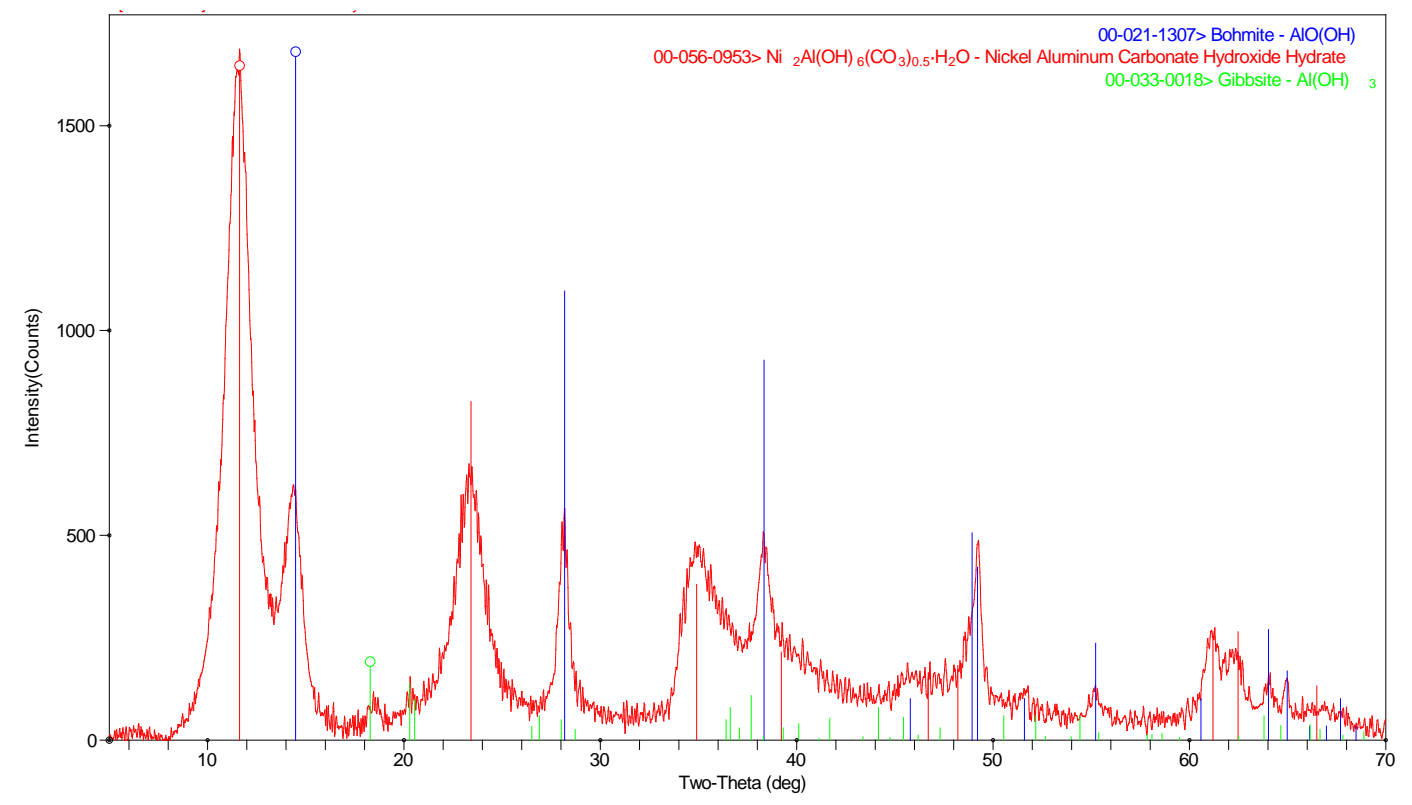

Figure 3-1. PXRD of Test 30 showing the presence of both boehmite and gibbsite phases. 


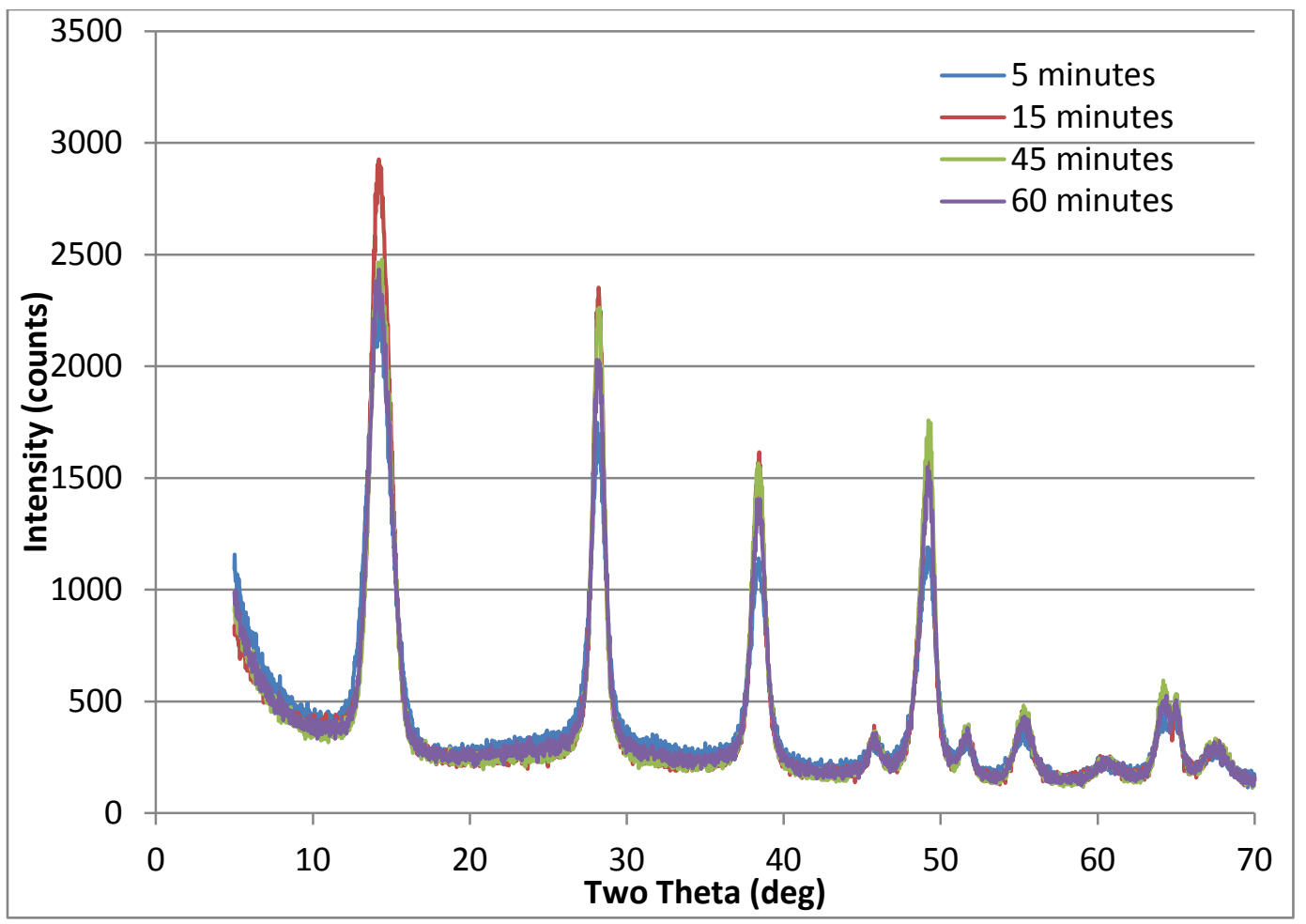

Figure 3-2. PXRD of Test 22 after variable times at $150{ }^{\circ} \mathrm{C}$. Results show the formation of only the boehmite phase for all time points.

At $75{ }^{\circ} \mathrm{C}$ a mixture of phases was obtained for each test. Bayerite was present in each of the products at $75{ }^{\circ} \mathrm{C}$, most commonly in a mixture with gibbsite. In the absence of additional metal cation, when the reactions were performed using microwave heating, all three phases were obtained. This was also true in the presence of 0.01 molar equivalents of $\mathrm{Fe}^{3+}$ and $\mathrm{Cr}^{3+}$. At a higher concentration of $\mathrm{Cr}^{3+}$ ( 0.2 equivalents), the formation of gibbsite was suppressed and the product was a mixture of bayerite and boehmite.

Tests 92-96 examined the formation of products in the absence of additional metal cation, over time, at $75{ }^{\circ} \mathrm{C}$. In contrast to the tests with additional metal cations at $75{ }^{\circ} \mathrm{C}$ using microwave heating, these tests used a shaker oven for heating. Interestingly, analysis of the products from these tests showed the possible formation of a fourth phase, nordstrandite, which was not observed in any other samples. The products all contained a mixture of bayerite, gibbsite, boehmite, and nordstrandite. There did not appear to be any change in the phases obtained with increased heating time, up to a maximum heating time of 24 hours. Figure 3-3 compares the results from tests 92-96, with test 71 . Test 71 is identical to test 92, with the exception of the heating method. Test 71 was heated to $75{ }^{\circ} \mathrm{C}$ for 1 hour using microwave heating, while test 92 was heating to $75^{\circ} \mathrm{C}$ for 1 hour using a shaker oven. 


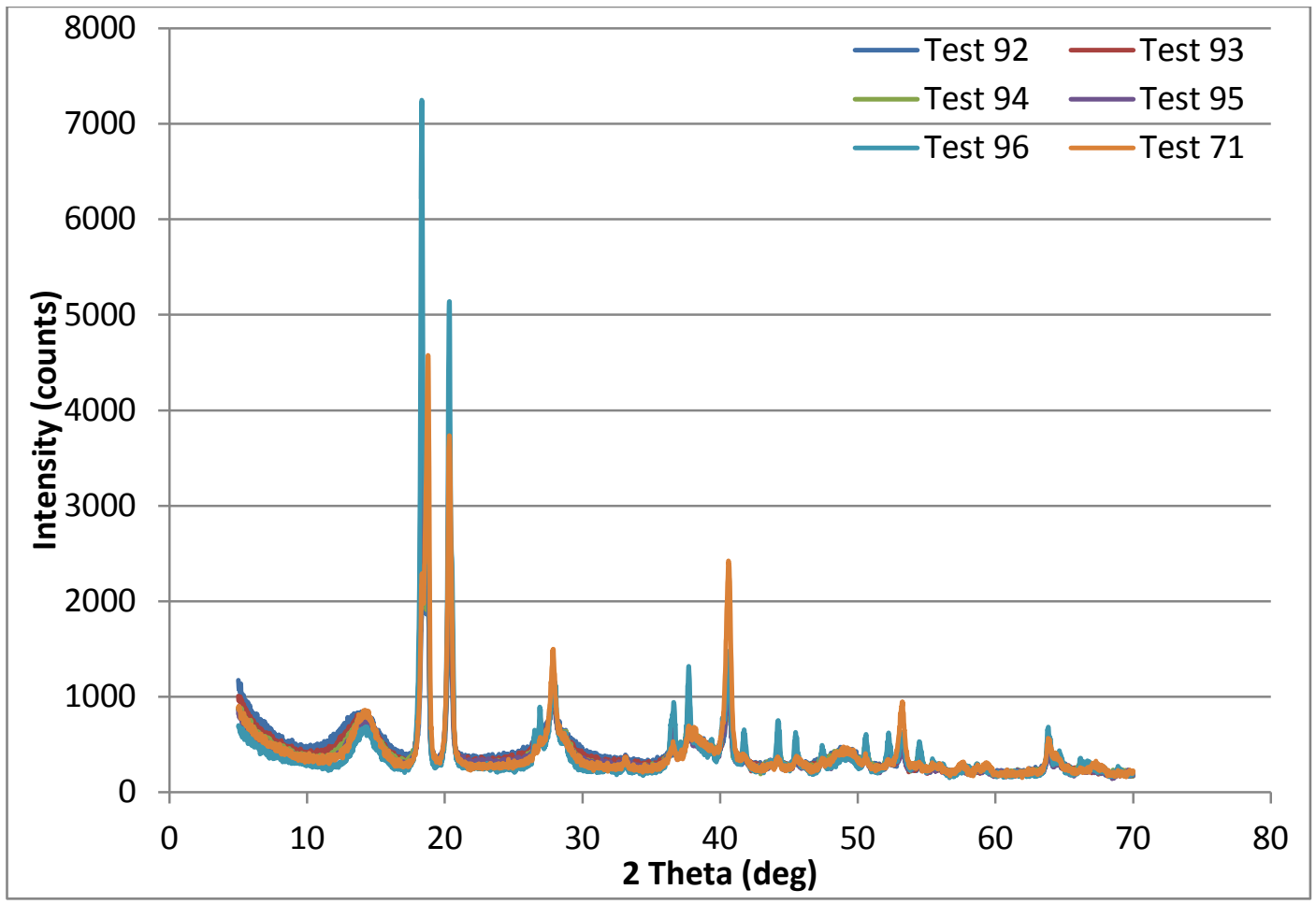

Figure 3-3. PXRD of Test 71 compared to the PXRD of Tests $92-96$.

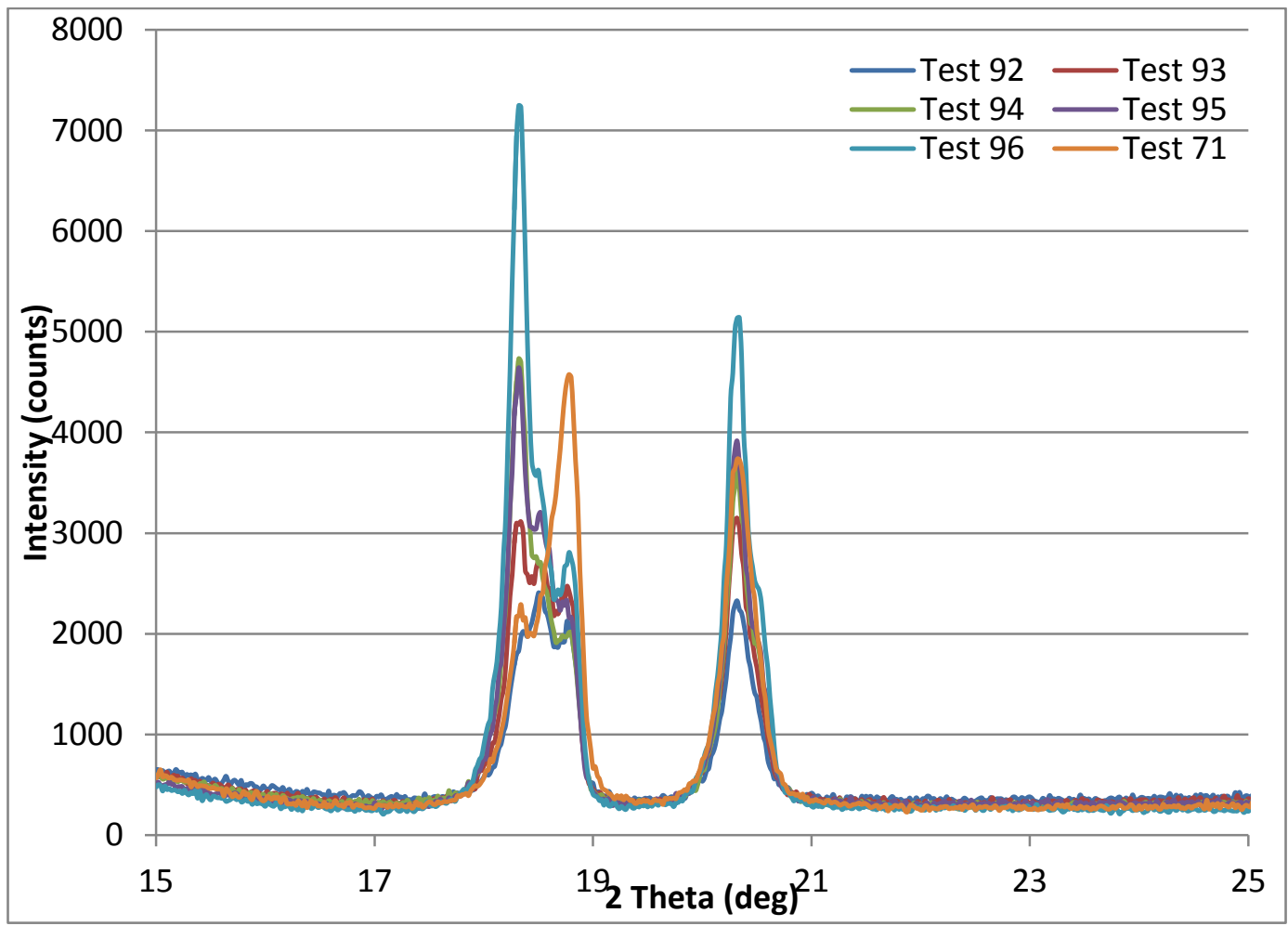

Figure 3-4. PXRD of Test 71 and $92-96$ showing difference in peaks between $18-19^{\circ} 2$ theta. Test 71 shows a larger amount of bayerite as evidenced by the peak at $18.8^{\circ}$, whereas Tests 92-96 show larger amounts of gibbsite as evidenced by the peak at $18.3^{\circ}$. The peak at $\sim 18.5^{\circ}$ indicates the presence of nordstrandite, which appears to be absent in Test 71. 
At room temperature, in the absence of additional metal ion, a mixture of bayerite and gibbsite was obtained. Although the reactions were performed at room temperature, the products were heated to $50{ }^{\circ} \mathrm{C}$ for several hours to dry the solids. The addition of metal ion suppressed the formation of the gibbsite phase, resulting in products containing only the bayerite phase, with a couple of exceptions. The addition of 0.2 equivalents of $\mathrm{Ni}^{2+}$ or 0.01 equivalents of $\mathrm{Cr}^{3+}$ produced a mixture of bayerite and gibbsite, with similar relative amounts to what was seen in the absence of metal ions.

\subsection{Conclusions}

In general, temperature was found to have the greatest impact on the phase formed upon the reaction of aluminum nitrate with sodium hydroxide. At $150{ }^{\circ} \mathrm{C}$, boehmite is the only phase obtained, independent of the presence of other metal cations, with only one exception where a small amount of gibbsite was also detected in the product when 0.2 equivalents of $\mathrm{Ni}^{2+}$ was present. At $75{ }^{\circ} \mathrm{C}$, a mixture of phases is obtained, most commonly including bayerite and gibbsite; however, boehmite is also formed under some conditions, including in the absence of additional metal ion. Therefore, the presence of an additional metal cation at $75{ }^{\circ} \mathrm{C}$ appears to suppress the formation of the boehmite phase. At room temperature, in the absence of additional metal ion, a mixture of bayerite and gibbsite is obtained. The addition of another transition metal cation suppresses the formation of gibbsite, with a couple of exceptions ( 0.2 equivalents of $\mathrm{Ni}^{2+}$ or 0.01 equivalents of $\mathrm{Cr}^{3+}$ ) where both phases are still obtained. 


\subsection{References}

1. G. Zorpette, "Hanford's Tank Wasteland.” Sci. Am. 1996, May, 88.

2. B. C. Bunker, J. W. Virden, B. Kuhn, and R. Quinn, "Nuclear Materials, Radioactive Tank Wastes.” Encyclopedia of Energy and the Environment; John Wiley \& Sons: New York, 1995; Vol. 4.

3. D. T. Hobbs and C. J. Coleman, "Characterization of High-Level Waste Saltcake Stored at the Savannah River Site.” Raioact. Waste Manage. Environ. Restor. 1999, 21, 235.

4. X. Gong, Z. Nie, M. Qian, J. Liu, L. A. Pederson, D. T. Hobbs, and N. G. McDuffie, "Gibbsite to Boehmite Transformation in Strongly Caustic and Nitrate Environments." Ind. Eng. Chem. Res. 2003, 42, 2163-2170. 
SRNL-STI-2012-00136

Revision 0

Appendix A. Summary of Test Conditions and Results 
Table A-1. Summary of Test Conditions and Results

\begin{tabular}{|c|c|c|c|c|c|c|}
\hline Test ID & [Al] (M) & Metal & Eq. M per Al & Rxn Temp. & Rxn Time & Al Product \\
\hline 14 & 0.25 & none & $\mathrm{n} / \mathrm{a}$ & $150^{\circ} \mathrm{C}$ & $1 \mathrm{~h}$ & boehmite \\
\hline 15 & 0.5 & none & $\mathrm{n} / \mathrm{a}$ & $150^{\circ} \mathrm{C}$ & $1 \mathrm{~h}$ & boehmite \\
\hline 16 & 1 & none & $\mathrm{n} / \mathrm{a}$ & $150^{\circ} \mathrm{C}$ & $1 \mathrm{~h}$ & boehmite \\
\hline $16 \mathrm{~b}$ & 1 & none & $\mathrm{n} / \mathrm{a}$ & room temp. & $2.5 \mathrm{~h}$ & bayerite, gibbsite \\
\hline 17 & 1.5 & none & $\mathrm{n} / \mathrm{a}$ & $150^{\circ} \mathrm{C}$ & $1 \mathrm{~h}$ & boehmite \\
\hline 18 & 2 & none & $\mathrm{n} / \mathrm{a}$ & $150^{\circ} \mathrm{C}$ & $1 \mathrm{~h}$ & boehmite \\
\hline 22 & 1 & none & $\mathrm{n} / \mathrm{a}$ & $150^{\circ} \mathrm{C}$ & $5-60 \mathrm{~min}$ & boehmite \\
\hline 23 & 1 & $\mathrm{Fe}(\mathrm{III})$ & 0.01 & $150^{\circ} \mathrm{C}$ & $1 \mathrm{~h}$ & boehmite \\
\hline 24 & 1 & $\mathrm{Fe}(\mathrm{III})$ & 0.05 & $150^{\circ} \mathrm{C}$ & $1 \mathrm{~h}$ & boehmite \\
\hline 25 & 1 & $\mathrm{Fe}(\mathrm{III})$ & 0.1 & $150^{\circ} \mathrm{C}$ & $1 \mathrm{~h}$ & boehmite \\
\hline 26 & 1 & Fe(III) & 0.2 & $150^{\circ} \mathrm{C}$ & $1 \mathrm{~h}$ & boehmite \\
\hline 27 & 1 & $\mathrm{Ni}(\mathrm{II})$ & 0.01 & $150^{\circ} \mathrm{C}$ & $1 \mathrm{~h}$ & boehmite \\
\hline 28 & 1 & $\mathrm{Ni}(\mathrm{II})$ & 0.05 & $150^{\circ} \mathrm{C}$ & $1 \mathrm{~h}$ & boehmite \\
\hline 29 & 1 & $\mathrm{Ni}(\mathrm{II})$ & 0.1 & $150^{\circ} \mathrm{C}$ & $1 \mathrm{~h}$ & boehmite \\
\hline 30 & 1 & $\mathrm{Ni}(\mathrm{II})$ & 0.2 & $150^{\circ} \mathrm{C}$ & $1 \mathrm{~h}$ & boehmite, gibbsite \\
\hline 31 & 1 & Cr(III) & 0.01 & $150^{\circ} \mathrm{C}$ & $1 \mathrm{~h}$ & boehmite \\
\hline 32 & 1 & Cr(III) & 0.05 & $150^{\circ} \mathrm{C}$ & $1 \mathrm{~h}$ & boehmite \\
\hline 33 & 1 & Cr(III) & 0.1 & $150^{\circ} \mathrm{C}$ & $1 \mathrm{~h}$ & boehmite \\
\hline 34 & 1 & Cr(III) & 0.2 & $150^{\circ} \mathrm{C}$ & $1 \mathrm{~h}$ & boehmite \\
\hline 35 & 1 & Mn(II) & 0.01 & $150^{\circ} \mathrm{C}$ & $1 \mathrm{~h}$ & boehmite \\
\hline 36 & 1 & Mn(II) & 0.05 & $150^{\circ} \mathrm{C}$ & $1 \mathrm{~h}$ & boehmite \\
\hline 37 & 1 & $\mathrm{Mn}(\mathrm{II})$ & 0.1 & $150^{\circ} \mathrm{C}$ & $1 \mathrm{~h}$ & boehmite \\
\hline 38 & 1 & Mn(II) & 0.2 & $150^{\circ} \mathrm{C}$ & $1 \mathrm{~h}$ & boehmite \\
\hline 39 & 1 & $\mathrm{Fe}(\mathrm{III})$ & 0.01 & room temp. & $1 \mathrm{~h}$ & bayerite \\
\hline 42 & 1 & $\mathrm{Fe}(\mathrm{III})$ & 0.2 & room temp. & $1 \mathrm{~h}$ & bayerite \\
\hline 43 & 1 & $\mathrm{Ni}(\mathrm{II})$ & 0.01 & room temp. & $1 \mathrm{~h}$ & bayerite \\
\hline 46 & 1 & $\mathrm{Ni}(\mathrm{II})$ & 0.2 & room temp. & $1 \mathrm{~h}$ & bayerite, gibbsite \\
\hline 47 & 1 & Cr(III) & 0.01 & room temp. & $1 \mathrm{~h}$ & bayerite, gibbsite \\
\hline 50 & 1 & Cr(III) & 0.2 & room temp. & $1 \mathrm{~h}$ & bayerite \\
\hline 51 & 1 & Mn(II) & 0.01 & room temp. & $1 \mathrm{~h}$ & bayerite \\
\hline 54 & 1 & Mn(II) & 0.2 & room temp. & $1 \mathrm{~h}$ & bayerite \\
\hline
\end{tabular}

$\mathrm{n} / \mathrm{a}=$ not applicable 
Table A-1 Continued.

\begin{tabular}{|c|c|c|c|c|c|c|}
\hline Test ID & [AI] (M) & Metal & Eq. M per Al & Rxn Temp. & Rxn Time & Al Product \\
\hline 55 & 1 & $\mathrm{Fe}(\mathrm{III})$ & 0.01 & $75^{\circ} \mathrm{C}$ & $1 \mathrm{~h}$ & $\begin{array}{c}\text { bayerite, gibbsite, } \\
\text { boehmite }\end{array}$ \\
\hline 58 & 1 & Fe(III) & 0.2 & $75^{\circ} \mathrm{C}$ & $1 \mathrm{~h}$ & bayerite, gibbsite \\
\hline 59 & 1 & $\mathrm{Ni}(\mathrm{II})$ & 0.01 & $75^{\circ} \mathrm{C}$ & $1 \mathrm{~h}$ & bayerite, gibbsite \\
\hline 62 & 1 & $\mathrm{Ni}(\mathrm{II})$ & 0.2 & $75^{\circ} \mathrm{C}$ & $1 \mathrm{~h}$ & bayerite, gibbsite \\
\hline 63 & 1 & Cr(III) & 0.01 & $75^{\circ} \mathrm{C}$ & $1 \mathrm{~h}$ & $\begin{array}{c}\text { bayerite, gibbsite, } \\
\text { boehmite }\end{array}$ \\
\hline 66 & 1 & $\mathrm{Cr}(\mathrm{III})$ & 0.2 & $75^{\circ} \mathrm{C}$ & $1 \mathrm{~h}$ & bayerite, boehmite \\
\hline 67 & 1 & $\mathrm{Mn}(\mathrm{II})$ & 0.01 & $75^{\circ} \mathrm{C}$ & $1 \mathrm{~h}$ & bayerite, gibbsite \\
\hline 70 & 1 & Mn(II) & 0.2 & $75^{\circ} \mathrm{C}$ & $1 \mathrm{~h}$ & bayerite, gibbsite \\
\hline 71 & 1 & none & $\mathrm{n} / \mathrm{a}$ & $75^{\circ} \mathrm{C}$ & $1 \mathrm{~h}$ & $\begin{array}{c}\text { bayerite, gibbsite, } \\
\text { boehmite }\end{array}$ \\
\hline 92 & 1 & none & $\mathrm{n} / \mathrm{a}$ & $75^{\circ} \mathrm{C}$ & $1 \mathrm{~h}$ & $\begin{array}{c}\text { bayerite, gibbsite, } \\
\text { boehmite, } \\
\text { (nordstrandite?) }\end{array}$ \\
\hline 93 & 1 & none & $\mathrm{n} / \mathrm{a}$ & $75^{\circ} \mathrm{C}$ & $2 \mathrm{~h}$ & $\begin{array}{c}\text { bayerite, gibbsite, } \\
\text { boehmite, } \\
\text { (nordstrandite?) }\end{array}$ \\
\hline 94 & 1 & none & $\mathrm{n} / \mathrm{a}$ & $75^{\circ} \mathrm{C}$ & $4 \mathrm{~h}$ & $\begin{array}{c}\text { bayerite, gibbsite, } \\
\text { boehmite, } \\
\text { (nordstrandite?) }\end{array}$ \\
\hline 95 & 1 & none & $\mathrm{n} / \mathrm{a}$ & $75^{\circ} \mathrm{C}$ & $8 \mathrm{~h}$ & $\begin{array}{c}\text { bayerite, gibbsite, } \\
\text { boehmite, } \\
\text { (nordstrandite?) }\end{array}$ \\
\hline 96 & 1 & none & $\mathrm{n} / \mathrm{a}$ & $75^{\circ} \mathrm{C}$ & $24 \mathrm{~h}$ & $\begin{array}{c}\text { bayerite, gibbsite, } \\
\text { boehmite, } \\
\text { (nordstrandite?) }\end{array}$ \\
\hline
\end{tabular}

$\mathrm{n} / \mathrm{a}=$ not applicable 


\section{Distribution:}

K. M. Fox, 999-W

S. D. Fink, 773-A

B. J. Giddings, 786-5A

C. C. Herman, 999-W

S. L. Marra, 773-A

F. M. Pennebaker, 773-42A

W. R. Wilmarth, 773-A

Records Administration (EDWS)

K. M. L. Taylor-Pashow, 773-A

D. T. Hobbs, 773-A

F. F. Fondeur, 773-A

M. S. Hay, 773-42A

J. M. Bricker, 704-27S

T. L. Fellinger, 704-26S

J. M. Gillam, 766-H

B. A. Hamm, 766-H

E. W. Holtzscheiter, 704-15S

M. T. Keefer, 766-H

D. D. Larsen, 766-H

J. E. Occhipinti, 704-S

J. W. Ray, 704-S

H. B. Shah, 766-H

D. C. Sherburne, 704-S

A. V. Staub, 704-27S

M. E. Stone, 999-W

P. R. Jackson, DOE-SR, 703-46A

K. H. Subramanian, 766-H
C. Wilson, 773-A

C. E. Duffey, 704-61H

A. W. Wiggins, 704-60H

E. J. Freed, 776-H

D. J. Martin, 241-152H 